Chirurgia (2019) 114: 732-738

No. 6, November - December

Copyright $\odot$ Celsius

http://dx.doi.org/10.21614/chirurgia.114.6.732

\title{
Metabolic and Hormonal Changes after Sleeve Gastrectomy and Mini Gastric Bypass in a Rat Model of Induced Type 2 Diabetes Mellitus and Obesity
}

\author{
Laurian Stoica $^{1,2}$, Amadeus Dobrescu ${ }^{1,2}$, Alexandru Isaic ${ }^{1,2}$, Gabriel Verdeș ${ }^{1,2}$, Cristi Tarța ${ }^{1,2}$, Fulger Lazăr ${ }^{1,2}$ \\ "Victor Babeș" University of Medicine and Pharmacy Timișoara, Romania \\ ${ }^{2} I^{\text {nd }}$ Surgery Clinic, Timișoara Emergency County Hospital, Romania
}

Corresponding author:

Dobrescu Amadeus, MD

Bld Liviu Rebreanu 156, Timișoara

300723, Romania

E-mail: amadeusdobrescu@yahoo.com

*Dr Stoica and Dr Dobrescu contributed

in equal parts to the writing of this paper

Abbreviations:

SG - sleeve gastrectomy;

SAGB - single-anastomosis gastric

bypass:

MGB - mini-gastric bypass;

RYGB - RouX-en-Y bypass.

\section{Rezumat}

Modificări metabolice și hormonale după gastrectomie longitudinală și MGB la model bazat pe șobolan cu diabet și obezitate

Introducere: Obezitatea este o problemă cu implicații sociale, economice şi medicale în lume, iar în ultimii ani chirurgia bariatrică s-a dovedit capabilă în a rezolva această problemă. Am efectuat un studiu experimental având ca scop compararea modificărilor metabolice şi hormonale după operația gastrectomie longitudinală şi mini gastric by-pass, două proceduri bariatrice promițătoare.

Material şi Metode: Am efectuat un studiu bazat pe model animal la şobolani cărora li s-a indus diabet zaharat tip 2 şi obezitate, împărțiți în trei loturi: un lot care a urmat procedura gastrectomie longitudinală, un lot mini gastric by-pass şi un lot martor, cărora li s-a măsurat glycemia, profilul lipidic, nivelele de grelinei şi insulinei înainte şi după operații.

Rezultate: Rezultatele au arătat scăderi semnificative ale glicemiei a jeun $(p<0.05)$, a profilului lipidic şi a nivelului grelinei în rândul lotului cu mini gastric bypass comparativ cu gastrectomia longitudinală.

Concluzii: Acest studiu demonstrează că atât gastrectomia longitudinală cât şi mini gastric by-pass-ul sunt două intervenții eficiente pentru tratarea obezității morbide şi a diabetului zaharat tip 2, iar ambele proceduri pot îmbunătătții semnificativ schimbările metabolice legate de obezitate. 
Cuvinte cheie: obezitate, diabet zaharat, chirurgie bariatrică, mini gastric bypass, gastrectomie longitudinală

\begin{abstract}
Introduction: Obesity is one of the leading causes of social, economic and health problems throughout the world and in the past years bariatric surgery has emerged as a method to alleviate this problem. We have conducted an experimental study aimed at comparing the metabolic and hormonal changes after sleeve gastrectomy and mini gastric by-pass, two bariatric procedures showing promising results.

Material and Methods: We have designed a study using a rat model with induced type 2 diabetes mellitus and obesity divided into three groups: a sleeve gastrectomy group, a mini gastric by-pass group and a sham operated group, all of which had their glycemia, lipid profile, ghrelin and insulin levels measured before and after the procedures.

Results: The results showed a significant decrease $(\mathrm{p}<0.05)$ in fasting glucose levels, lipid profile and ghrelin levels in the mini gastric bypass compared to the sleeve gastrectomy group.

Conclusions: This study has demonstrated that both SG and MGB are effective treatments for morbid obesity and T2DM and both procedures can significantly resolve obesity-related metabolic changes.
\end{abstract}

Key words: obesity, diabetes mellitus, bariatric surgery, mini gastric bypass, sleeve gastrectomy

\section{Introduction}

Of all diseases plaguing the Western world in the 21st century, obesity and overweight are one of the most widespread. Affecting more than 650 million adults according to the World Health Organization in 2016 (1), it is both a public health and an economic burden. Obesity and diabetes mellitus remain the leading causes of reduced health and life span throughout the world (2). The relationship that links obesity and diabetes mellitus to the regulation of metabolism and hormonal changes is being increasingly studied. Both type 2 diabetes mellitus and obesity are associated with insulin resistance through the increased levels of nonesterified fatty acids, glycerol, hormones, cytokines and proinflammatory substances (3). Lipid profile changes are also a usual finding in obese patients with T2DM.

Although the ideal treatment consists of lifestyle changes including diet and physical activity, the most resorted method is through weight reducing medication which bears little long-term favorable results, leading to variable weight changes over time.

Bariatric surgery has become one of the most efficient methods for treating morbid obesity, not only because it dramatically reduces weight loss, but also by resolving associated comorbidity as well (4). Post-operative weight loss is also stimulated by the decreased production of hormones related to obesity such as ghrelin, which is vastly produced by the cells of the gastric fundus, the majority of which is removed during sleeve gastrectomy (SG). Ghrelin stimulates appetite, increases gastric motility and secretion, increases growth hormone secretion and reduces fat utilization (5). Moreover, ghrelin decreases insulin secretion and ghrelin secretion is controlled by glucagon, insulin and leptin (6). Lately, another surgical technique known as single-anastomosis gastric bypass (SAGB) or mini-gastric bypass (MGB) has been developed 
(7). Initially described by Rutledge (8), this procedure proposes a simplification of Rouxen-Y bypass (RYGB) by performing a single anastomosis, with a significant reduction of technical complexity, shorter operative time and a potential reduction in morbidity and mortality (7). However, changes in ghrelin levels were also observed after mini gastric bypass (MGB).

Insulin, produced by the beta cells of the islets of Lagerhans of the pancreas, promotes transport of glucose from the circulation into tissues, it stimulates uptake of glucose and deposition of glycogen in the liver. It decreases release of glucose by the liver and also decreases food intake and increases energy expenditure acting in the hypothalamus.

Some of the studies have shown similar results between LSG and MGB, (9), while other studies have shown different result.

The purpose of this study is to compare the surgical outcomes of LSG and MGB in the treatment of morbid obesity, regarding metabolic and hormonal changes, and weight loss. in a rat model of induced type 2 diabetes mellitus.

\section{Material and Methods}

\section{Experimental Animals}

The following protocol was used by the authors for other rat model experiments involving gastric sleeve and gastric plication (10).

We have used fifteen male Wistar rats provided by the Pius Brînzeu Center for Flap Surgery and Microsurgery of the "Victor Babeş" University if Medicine and Pharmacy Timişoara, who were reared in separate cages under controlled temperature $\left(21-23^{\circ} \mathrm{C}\right)$, humidity (50-55\%), and light (12 hours light, 12 hours dark, lights turned on at 7 o'clock). All experiments were conducted having the approval of the local Ethics Committee of the "Victor Babeş" University of Medicine and Pharmacy in compliance with the European Union laws on animal protection (86/609/EC).

\section{Study Design}

We have begun with 9 weeks-old rats who were first acclimatized to the facilities for one month before study commencement. During the first 36 weeks, free access to DIO food (Bio Serv ${ }^{\circledR}$ F3282 - Mouse Diet, High Fat, Fat Calories - 60\%) and tap water was provided for them. Afterwards the rats were divided into three weight-matched groups: group SG to undergo sleeve gastrectomy $(n=5)$, group MGBP to undergo mini gastric by-pass $(n=5)$ and a control group SO to undergo sham surgery $(n=5)$. After the surgical procedures, normal rat chow diet (Bio Serv® F4031) was fed to the rats until the end of experiment. Additional blood samples were drawn after these 4 weeks.

\section{Surgical Procedures and Anesthesia Protocol}

After a 14 hours overnight fast with access only to water, the rats were introduced into a $20 / 10$ $\mathrm{cm}$ induction chamber for anesthesia, using Isoflurane $^{\circledR}$ (Anesteran 99.9\% - Rompharm ${ }^{\mathrm{TM}}$ ) $5 \%$ in a mixture with oxygen at flow of 2.5 $\mathrm{L} / \mathrm{min}$ debit based on spontaneous respiration. Once induction was achieved, isoflurane 1.5 $2.2 \%$ in a mixture with oxigen was administered through a cone mask for rodents at a flow of $2-2.2 \mathrm{~L} / \mathrm{min}$ (11). All surgeries were performed under sterile conditions. The rat was shaved and a povidone-iodine solution was applied to the skin.

In order to perform the sleeve gastrectomy, a $4 \mathrm{~cm}$ midline incision was made, the gastrosplenic ligament was divided and the stomach was externalized. Using a $10 \mathrm{Ch}$ orogastric tube, the stomach was calibrated for all procedures. A vascular clamp was placed along the greater curvature from the antrum to the fundus across the stomach which helped remove, using a scalpel, the main part of the corpus and fundus of the stomach. The stomach was then closed with 5-0 nonabsorbable polypropylene monofilament suture (Premilene B | Braun) in two layers in a continuous fashion. 
For the mini gastric by-pass a $4 \mathrm{~cm}$ midline incision was performed, the gastrosplenic ligament was divided and the stomach externalized. A vascular clamp was placed perpendicular on the lesser curvature and another one parallel to the greater curvature, thus sectioning the stomach and removing the excess parts of the fundus and corpus. The vertical section of the stomach was then closed with 5-0 non-absorbable polypropylene monofilament suture (PremileneB|Braun) in one layer in a continuous fashion, while the horizontal section of the stomach was anastomosed to the jejunum, to obtain between $20 \%$ $25 \%$ of bypassed small bowel. The rest of the stomach was then closed in the same fashion.

For the sham-operated groups, after performing a $4 \mathrm{~cm}$ upper midline incision, the stomach was externalized, manipulated, and then returned to the abdomen. The peritoneal cavity was cleaned with saline solution and the abdominal wall was closed with running 3-0 polyglactin acid suture. The skin was then sewed with 3-0 running intracutaneous absorbable multifilament coated polyglactin suture (Vicryl Ethicon).

All animals were given $5 \mathrm{ml}$ sterile warmed saline intraabdominally to avoid dehydration and allowed to recover spontaneously from anaesthesia and surgery.

\section{Postoperative Care}

All rats received prophylactic antibiotherapy administered after surgery and for the next three days. Anti-inflammatories were also concomitantly administered. All animals included in the study survived for the entire duration of the experiment.

\section{Blood collection and analysis}

Fasting blood glucose was measured from the tail of the rat, using an ACCU- CHEK TM glucometer. After performing the laparotomy, blood was drawn from the inferior vena cava which was used to determine the lipid profile (total cholesterol, LDL cholesterol, HDL cholesterol, tryglicerides), plasma ghrelin and insulin levels by using spectrophotometry. A calibrated Sartorius scale was used to weight the rats. Percentage total weight loss (\%TWL) was calculated as the per cent of body weight loss, which was calculated from the equation: (preinterventional body weight - final body weight) $\times$ 100/pre-interventional body weight (12).

\section{Statistical Analysis}

Results are shown as means \pm SD. Data was analyzed using Microsoft Excel ${ }^{\mathrm{TM}}$. One-way analysis of variance ANOVA and student t-test were used for comparison of the means between the groups. A p value $<0.05$ was considered statistically significant.

\section{Results}

Weight changes were measured between weeks 0, 36 (before surgery) and 40 (after surgery). While the sham operated group showed an increase in weight even after surgery, the mini gastric by-pass group had a weight decrease from $784 \mathrm{~g}$ to $631.1 \mathrm{~g} \quad(\mathrm{p}<0.05)$ and the sleeve gastrectomy group a decrease from $777.4 \mathrm{~g}$ to $648.8 \mathrm{~g}(\mathrm{p}<0.05)($ Fig.1)

The total weight loss after surgery was greater in the mini gastric by-pass group (19.5 $\%)$ compared to the sleeve gastrectomy group (Fig. 2)

Mean fasting glucose levels decreased between preoperative time and 4 weeks after surgery in all three groups as such: from 143 $\mathrm{mg} / \mathrm{dl}$ to $95 \mathrm{mg} / \mathrm{dl}$ in the sleeve gastrectomy group, from $149 \mathrm{mg} / \mathrm{dl}$ to $84 \mathrm{mg} / \mathrm{dl}$ in the mini gastric by-pass group and from $140 \mathrm{mg} / \mathrm{dl}$ to $105 \mathrm{mg} / \mathrm{dl}$ in the sham operated group (Fig. 3)

Tryglicerides levels decreased statistically significant between preoperative time and 4 weeks after in the sleeve gastrectomy group ( $p=0.004)$ as compared to the mini gastric by-pass group. Total cholesterol levels decreased statistically significant in the mini gastric by-pass group $(p=0.05)$ compared to the sleeve gastrectomy group. Also HDL cholesterol levels increased statistically significant in the mini gastric by-pass group $(p=0.004)$ compared to the sleeve gastrectomy 
Figure 1. Weight evolution between groups

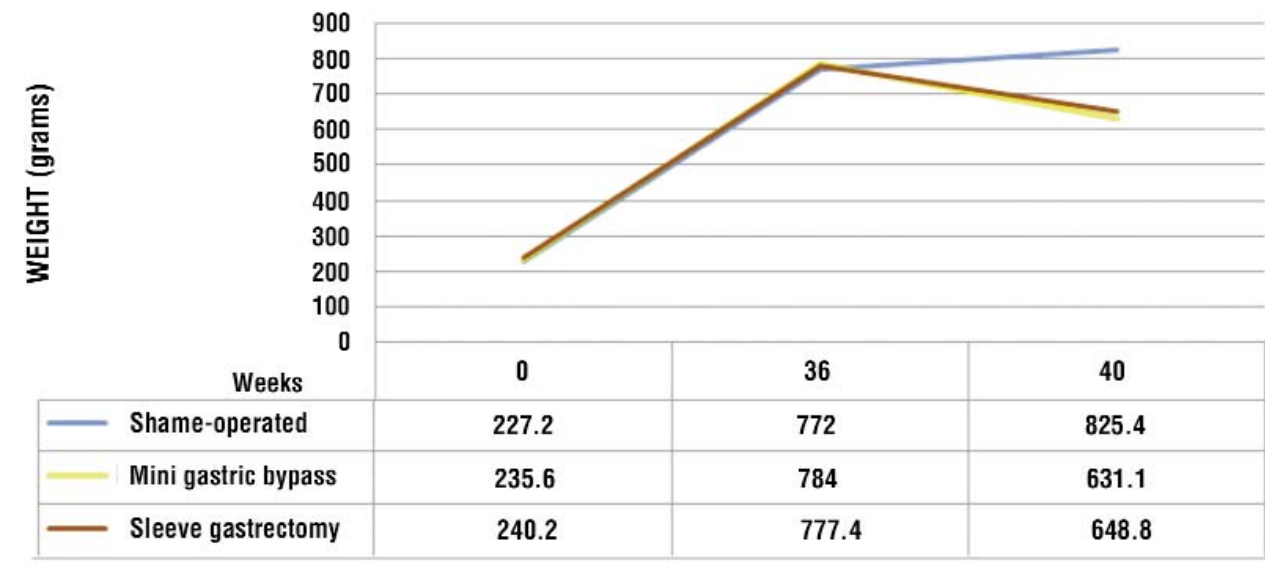

TWL (\%)

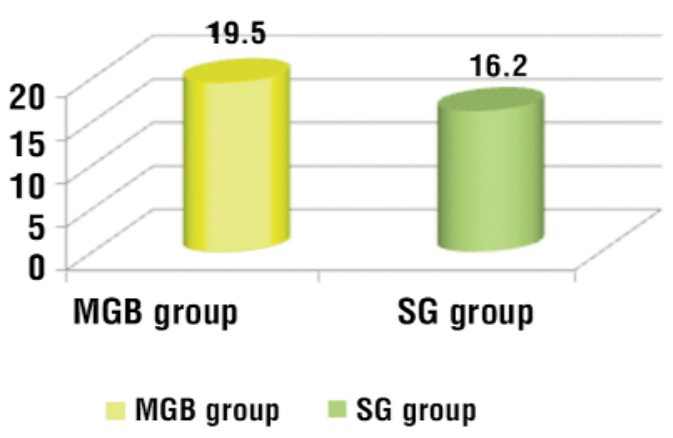

Figure 2. Total weight loss between groups

group. However, both groups displayed significant decreases in LDL cholesterol levels ( $p=0.004$ in the sleeve gastrectomy group and $\mathrm{p}=0.001$ in the mini gastric by-pass group) (Table. 1).

Ghrelin levels decreased statistically significant after surgery both in the sleeve gastrectomy and the mini by-pass group ( $p<0.05)$, while insulin levels decreased

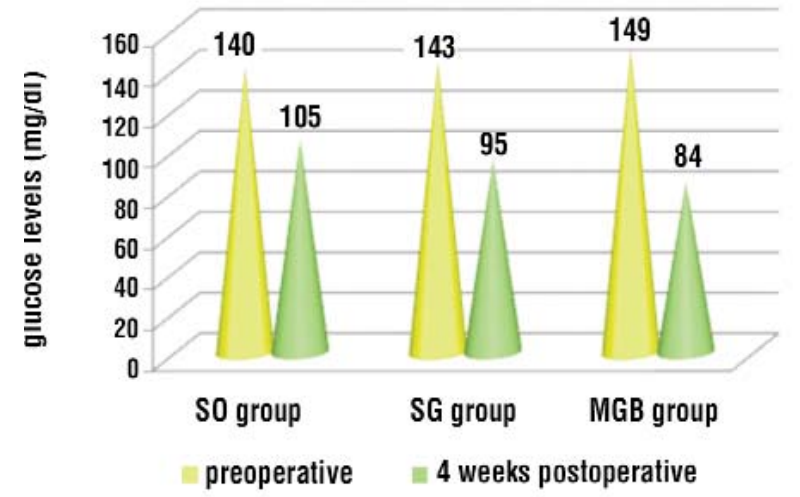

Figure 3. Mean fasting glucose levels among groups

statistically significant only in the sleeve gastrectomy group (Table. 2).

\section{Discussions}

Obesity and obesity-related comorbidities has been shown to have become one of the most enormous challenges we face in healthcare as well as in the global economy $(13,14,15,16)$.

Table 1. Lipid profile changes among groups

\begin{tabular}{|c|c|c|c|c|c|c|c|c|c|}
\hline & \multicolumn{3}{|c|}{ SG group } & \multicolumn{3}{|c|}{ MGB group } & \multicolumn{3}{|c|}{ SO group } \\
\hline & preoperative & postoperative & $p$ value & preoperative & postoperative & $p$ value & preoperative & postoperative & $p$ value \\
\hline $\mathrm{TG}(\mathrm{mg} / \mathrm{dl})$ & $161.4 \pm 35.89$ & $150.6 \pm 40.36$ & 0.004 & $175.6 \pm 31.83$ & $146.2 \pm 33.46$ & 0.009 & $158.6 \pm 29.44$ & $155.2 \pm 38.15$ & NS \\
\hline $\mathrm{TC}(\mathrm{mg} / \mathrm{dl})$ & $138.4 \pm 14.87$ & $127.2 \pm 13.27$ & 0.006 & $129.6 \pm 13.01$ & $121.4 \pm 10.15$ & 0.05 & $131.4 \pm 13.84$ & $129.4 \pm 13.81$ & NS \\
\hline $\mathrm{HDL}(\mathrm{mg} / \mathrm{dl})$ & $52.2 \pm 9.09$ & $59 \pm 6.35$ & 0.008 & $54.4 \pm 5.33$ & $57.2 \pm 6.05$ & 0.004 & $55.8 \pm 9.47$ & $56.8 \pm 7.52$ & NS \\
\hline $\mathrm{LDL}(\mathrm{mg} / \mathrm{dl})$ & $95.4 \pm 15.56$ & $86.8 \pm 14.65$ & 0.004 & $96 \pm 12.88$ & $87.4 \pm 16.41$ & 0.001 & $91.6 \pm 12.4$ & $90.6 \pm 14 . .43$ & NS \\
\hline
\end{tabular}


Table 2. Acylated ghrelin and insulin levels

\begin{tabular}{|c|c|c|c|c|c|c|c|c|c|}
\hline & \multicolumn{3}{|c|}{ SG group } & \multicolumn{3}{|c|}{ MGB group } & \multicolumn{3}{|c|}{ SO group } \\
\hline & preoperative & postoperative & $p$ value & preoperative & postoperative & $p$ value & preoperative & postoperative & p value \\
\hline $\begin{array}{l}\text { Acylated Ghrelin } \\
\text { (ng/ml) }\end{array}$ & $3.15 \pm 0.53$ & $1.95 \pm 0.34$ & $p<0.05$ & $3.01 \pm 0.6$ & $2.74 \pm 0.55$ & $p<0.05$ & $2.7 \pm 0.33$ & $3.04 \pm 0.5$ & NS \\
\hline Insulin (ng/ml) & $4.4 \pm 0.9$ & $3.2 \pm 0.8$ & $p<0.05$ & $3.25 \pm 0.9$ & $3.9 \pm 0.4$ & NS & $4.04 \pm 1.1$ & $5.1 \pm 0.8$ & NS \\
\hline
\end{tabular}

Bariatric surgery is currently the best treatment for severe obesity, because it achieves better short-term and long-term results compared to behavioral approaches or medical treatment (17). LSG and RYGB are currently the most commonly performed bariatric operations, but MGB has been increasing $(17,18,19)$.

Our study in experimental rat models of SG and MGB have shown a decreasing in body weight compared to the control group. The higher EWL\% of MGB may be due to different mechanisms between MGB and SG. $\mathrm{SG}$ is a restrictive procedure, but MGB is a restrictive and malabsorptive procedure (20).

The results of our study showed amelioration in fasting glucose levels. Rats submitted to mini gastric by pass showed a significant improvement of glycemic control compared to the shame-operated group. Wang (20) showed better results for remission rate of T2DM in the MGB intervention compared to the sleeve gastrectomy.

Four weeks after surgery, the positive effects of sleeve gastrectomy and mini gastric were observed in the lipid profile changes. In our study we evaluated the cluster of metabolic abnormalities known as metabolic syndrome in morbidly obese patients. Trygliceride levels showed a significant improvement in the sleeve gastrectomy group, which based on current clinical evidence play a huge part in dyslipidemic atherogenesis. Decreased trygliceride levels offer a substantial reduction of cardiovascular events. While total cholesterol and LDL cholesterol levels decreased in both groups, HDL cholesterol showed a small increase in the mini gastric by-pass group. Lee et al. (21) have stated resolution of metabolic syndrome after a mean follow-up of 5.6 years after MGB (22)
Ghrelin is a 28 amino-acids peptide with strong growth hormone $(\mathrm{GH})$ releasing activity, and is mainly produced by the X/A-like cells of the oxyntic glands in the fundus of the stomach, which are nowadays referred to as ghrelin cells or Gr cells. Production of ghrelin is attenuated by the presence and stimulated by the absence of food in the stomach (23), This study shows that plasma acethylated ghrelin levels decrease after gastric restrictive surgery. Other action of ghrelin is inhibition of insulin-producing. Rats submitted to SG have shown a decrease insulin plasma levels, while the MGB group showed an increased plasma insulin levels. Umeda (24) demonstrated a progressive improvement in glycemic control, and improvement in both insulin sensitivity and production after bariatric surgery.

Animal experiments remain essential to understand the fundamental mechanisms involving obesity. The current excellence of animal care standards are consistent with the experimental conditions needed when conducting research (25).

The major limitations of this study are the small sample who underwent surgery and the short postoperative follow-up time, but having in view it was an experimental study, group sizes are expected to be smaller.

\section{Conclusions}

This study has demonstrated that both SG and MGB are effective treatments for morbid obesity and T2DM. Both procedures can significantly resolve obesity-related metabolic changes.

\section{Acknowledgements}

This study was supported by a grant from the 
Victor Babes University of Medicine and Pharmacy Timisoara - Proiecte pentru tineri cercetatori programul II -C3 - TC - 2015 ACRONIM: OPTIM GALOP

\section{Conflict of Interest}

The authors declare that they have no conflict of interest

\section{References}

1. WHO Obesity and overweight https://www.who.int/news-room/ fact-sheets/detail/obesity-and-overweight

2. Ruiz HH, López Díez R, Arivazahagan L, Ramasamy R, Schmidt AM. Metabolism, Obesity, and Diabetes Mellitus Recent Studies in Cellular and Animal Models and Human Subjects Highlight Mechanisms and Consequences of Metabolic Dysfunction Arterioscler Thromb Vasc Biol. 2019;39:e166-e174.

3. Al-Goblan AS, Al-Alfi MA, Khan MZ. Mechanism linking diabetes, mellitus and obesity Diabetes. Metabolic Syndrome and Obesity: Targets and Therapy. 2014;7:587-591

4. Shivakumar S, Tantia 0, Goyal G, Chaudhuri T, Khanna S, Ahuja A et al. LSG vs MGB-OAGB-3 Year Follow-up Data: a Randomised Control Trial. Obes Surg. 2018;28(9):2820-2828.

5. Bužga M, Zavadilová V, Holéczy P, Svvagera Z, Švorc P, Foltys A, et al. Dietary intake and ghrelin and leptin changes after sleeve gastrectomy. Wideochir Inne Tech Maloinwazyjne. 2014;9(4): 554-561.

6. Toshihiko $Y$, Katsuya D, Hideyuki S, Masaru K, Oldbaatar D, Masanori N, et al. Ghrelin regulates insulin release and glycemia: physiological role and therapeutic potential. Curr Diabetes Rev 2008:4:18-23.

8. Chaim EA, Ramos AC, Cazzo E. Mini-gastric bypass: description of the technique and preliminary results. Arq Bras Cir Dig. 2017; 30(4):264-266. English, Portuguese

9. Magouliotis DE, Tasiopoulou VS, Svokos AA, Svokos KA, Sioka E, Zacharoulis D. One-Anastomosis Gastric Bypass Versus Sleeve Gastrectomy for Morbid Obesity: a Systematic Review and Metaanalysis. Obesity Surgery. 2017;27(9):2479-2487.

10. Dobrescu A, Stoica L, Mituletu M, Isaic A, Duta C, Verdes G, et al. Metabolic and Weight Changes After Bariatric Surgery in a Rat Model of Induced Type 2 Diabetes Mellitus and Obesity. Rev. Chim. (Bucharest). 2018;69(4):1030-1033.

11. Sarandan M, Guragata-Balasa C, Papurica M, Duta C, Hordovan E, Rus $C$, et al. Anesthesia in laparoscopic bariatric surgery (gastric sleeve) - preliminary experience. TMJ. 2011;61(1-2):26-31.

12. Moncada R, Becerril S, Rodríguez A, Méndez-Giménez L, Ramírez
B, Catalán V, et al. Sleeve Gastrectomy Reduces Body Weight and Improves Metabolic Profile also in Obesity-Prone Rats. Obes Surg. 2016;26:1537-1548.

13. Wang F-G, Yan W-M, Yan M, Song M-M. Outcomes of Mini vs Roux-en-Y gastric bypass: A meta-analysis and systematic review. International Journal of Surgery. 2018;56:7-14.

14. Danaei G, Finucane MM, Lu Y, Singh GM, Cowan MJ, Paciorek CJ, et al. National, Regional, and Global Trends in Fasting Plasma Glucose and Diabetes Prevalence since 1980: Systematic Analysis of Health Examination Surveys and Epidemiological Studies with 370 Country-Years and 2.7 Million Participants. Lancet. 2011;378: $31-40$.

15. Finucane MM, Stevens GA, Cowan MJ, Danaei G, Lin JK, Paciorek $\mathrm{CJ}$, et al. National, Regional, and Global Trends in Body-Mass Index since 1980: Systematic Analysis of Health Examination Surveys and Epidemiological Studies with 960 Country-Years and 9•1 Million Participants. The Lancet. 2011;377:557-567.

16. Ogden $\mathrm{CL}$, Carroll MD, Kit BK, Flegal KM. Prevalence of Obesity among Adults: United States, 2011-2012, NCHS Data Brief (2013), 18.

17. Jammu GS, Sharma R. A 7-Year Clinical Audit of 1107 Cases Comparing Sleeve Gastrectomy, Roux-En-Y Gastric Bypass, and Mini-Gastric Bypass, to Determine an Effective and Safe Bariatric and Metabolic Procedure. Obesity Surgery. 2015;26(5):926-932.

18. Noun R, Skaff J, Riachi E, Daher R, Antoun NA, Nasr M. One thousand consecutive minigastric bypass: short- and long-term outcome. Obes Surg. 2012;22:697-703.

19. Musella M, Susa A, Greco F, De Luca M, Manno E, Di Stefano C, et al. The laparoscopic mini-gastric bypass: the Italian experience: outcomes from 974 consecutive cases in a multi-center review. Surg Endosc. 2014;28:156-63.

20. Wang F-G, Yu Z-P, Yan W-M, Song MM. Comparison of safety and effectiveness between laparoscopic mini-gastric bypass and laparoscopic sleeve gastrectomy. A meta-analysis and systematic review. Medicine. 2017;96:50(e8924).

21. Lee WJ, Ser KH, Lee YC, Tsou JJ, Chen SC, Chen JC. Laparoscopic Roux-en-Y vs. mini-gastric bypass for the treatment of morbid obesity: a 10-year experience. Obes Surg. 2012 22(12):1827-1834.

22. Plamper A, Lingohr P, Nadal J, Rheinwalt K. P Comparison of minigastric bypass with sleeve gastrectomy in a mainly super-obese patient group: first results. Surgical Endoscopy. 2016;31(3): $1156-1162$.

23. Nijhuis J, van Dielen FMH, Buurman WA, Greve JWM. Ghrelin, Leptin and Insulin Levels after Restrictive Surgery: a 2-Year Followup Study. Obesity Surgery. 2004;14(6):783-787.

24. Umeda LM, Silva EA, Carneiro G, Arasaki CH, Geloneze B, Zanella MT. Early Improvement in Glycemic Control After Bariatric Surgery and Its Relationships with Insulin, GLP-1, and Glucagon Secretion in Type 2 Diabetic Patients. Obesity Surgery. 2011;21(7):896-901.

25. Workman P, Aboagye EO, Balkwill F, Balmain A, Bruder G, Chaplin DJ, et al. Guidelines for the welfare and use of animals in cancer research. Br J Cancer. 2010;102:1555-77. 